\title{
PEMBERDAYAAN PENGELOLAAN KEUANGAN DALAM MENINGKATKAN KEMAMPUAN MANAJERIAL BAGI PELAKU USAHA DI DESA WARNASARI KECAMATAN PANGALENGAN KABUPATEN BANDUNG
}

\author{
Nurhayati, Hj. Yayan Mulyana, Heri Erlangga \\ Jurusan Adm. Bisnis, Universitas Pasundan Bandung \\ nurhayati@unpas.ac.id, yayan.mulyana@unpas.ac.id, heri.erlangga@unpas.ac.id
}

\begin{abstract}
Abstrak
Di Desa Warnasari terdapat 3 dusun yang masing-masing dusun mempunyai unggulan masing-masing. Di setiap dusun pelaku usahanya tidak banyak hanya beberapa saja yang sudah start up. Progam pengabdian masyarakat ini bertujuan untuk mengedukasi para pelaku usaha di desa Warnasari. Masalah utama yang sering dihadapi oleh para pelaku usaha diantaranya adalah belum adanya kesadaran untuk melakukan pencatatan keuangan usaha karena minimnya pengetahuan tentang pembukuan keuangan, Metodologi pelaksanaan dalam pengabdian pada masyarakat ini dibagi menjadi 3 (tiga) tahap yaitu tahap awal yaitu Observasi dan wawancara langsung dengan mitra. Tahap pelaksanaan berupa: Pelatihan pembukuan keuangan sederhana yang dapat diaplikasikan oleh pelaku usaha. Tahap yang terakhir adalah tahap monitoring. Dengan melakukan metode coaching, dimana pemilik UMKM menunjukkan hasil pencatatan keuangannya dengan menceritakan hambatan dan kesulitan yang dihadapi dalam melakukan proses pencatatan. Kegiatan pengabdian kepada masyarakat pada pelaku usaha Di Desa Warnasari mendapat respon yang positif. Pelaku usaha mendapatkan wawasan baru, mengetahui dan termotivasi dalam menjalankan usahanya baik melalui pembukuan/pencatatan keuangan sederhana yang mudah diaplikasikan serta memupuk motivasi kewirausahaan. Pengelolaan usaha membutuhkan sistem yang terintegrasi yang saling terkait satu dengan yang lainnya. Saran nya adalah sebaiknya pelaku usaha meningkatkan kreativitas dan inovasi dengan memperluas jaringan usaha agar semakin meningkatkan penjualan dan pendapatan.
\end{abstract}

Kata Kunci : Permberdayaan Pengelolaan Keuangan 


\section{PENDAHULUAN}

Berdasarkan analisis situasi, pelaku usaha dalam menjalankan usahanya tersebut menemui beberapa masalah yang berkaitan dengan usahanya. Diantaranya adalah ;

a. Aspek Produksi

Bahan baku untuk pembuatan kerupuk kentang masih terbatas karena pelaku usaha hanya mengandalkan dari petani lokal saja apabila petani sedang panen kentang. Serta tidak produksi secara terus menerus karena keterbatasan bahan baku.

b. Aspek Sumber Daya Manusia

Sumber Daya Manusia yang dimiliki tidak mempunyai keahlian sendiri yang pada umumnya belajar secara otodidak dimana para pegawainya adalah keluarga sendiri dan memberdayakan tetangga yang terdekat terutama pada Hari Raya dan hari besar lainnya yang selalu tidak terpenuhinya pesanan.

c. Aspek Pemasaran

Karena pelaku usaha masih terbatas pengetahuan maka Pemasaran yang telah dilakukan hanya dengan memasarkan ke toko dan warung terdekat saja. Disamping itu karena produksi rumahan maka terbatasnya ruangan yang berada di rumah sehingga pemesanan produkpun terbatas

d. Aspek Permodalan

Pada aspek permodalan ini pelaku usaha belum mendapat bantuan terbatas pada modal yang dikeluarkan dari uang pribadi. Apabila ingin mendapatkan bantuan dari perbankan mereka tidak mempunyai agunan/jaminan yang cukup serta tidak adanya pencatatan keuangan. Juga terkendala dengan birokrasi yang memberatkan pelaku usaha..

Komitmen dari pelaku usaha memiliki peranan penting dalam menjaga kelangsungan hidup usaha. Berwirausaha merupakan salah satu upaya dalam memperoleh pendapatan keluarga. Progam pengabdian masyarakat ini bertujuan untuk mengedukasi para pelaku usaha di desa Warnasari. Masalah utama yang sering dihadapi oleh para pelaku usaha diantaranya adalah belum adanya kesadaran untuk melakukan pencatatan keuangan usaha karena minimnya pengetahuan tentang pembukuan keuangan, berakibat pada sistem keuangan usaha yang tidak dapat membedakan antara keuntungan usaha dan kas pribadi serta menurunnya motivasi jika dihadapkan dengan permasalahan usaha sehingga berdampak pada rendahnya dalam melakukan inovasiinovasi baru.

Untuk menentukan persoalan yang dihadapi oleh mitra, maka justifikasi kami Tim Pengusul memfasilitasi pelatihan pembukuan serta manajemen keuangan berdasarkan permintaan dari mitra. Dengan alasan kesulitan dalam memperoleh permodalan baik dari pemerintah maupun perbankan karena harus ada penyertaan laporan pembukuan. Oleh karena itu tim pengusul menyiapkan personal yang mempunyai kualifikasi di bidang pembukuan dan keuangan terutama pada saat pemberian training/pelatihan yang dibutuhkan oleh mitra.

Solusi yang ditawarkan dari kegiatan pengabdian kepada masyarakat ini yaitu pelaku usaha dapat mengelola pembukuan 
keuangan usahanya dengan baik dan sistematis, sehingga dapat menghasilkan laporan keuangan seusai dengan standar yang berlaku, sehingga dapat membantu kelancaran bantuan dari pihak ketiga (misalnya Bank) yang pada akhirnya dapat membangun kekuatan UMKM sehingga tercapai kesejahteraan masyarakat Indonesia secara adil dan merata. Selain itu, penerapan pembukuan sederhana juga dapat menciptakan budaya disiplin di dalam perusahaan.

Target dan luaran yang diharapkan dari kegiatan pengabdian masyarakat bagi pelaku usaha adalah: Diharapkan dalam kegiatan ini mampu membuat pembukuan sendiri agar tertib dalam melakukan pencatatan keuangannya sehingga dapat terukur pengeluaran dan pemasukannya serta keuntungan yang diperoleh.

Luaran nya adalah bahwa diharapkan pemilik usaha menjadi percaya diri dengan mempunyai laporan keuangan sendiri apabila melakukan peminjaman kepada fihak perbankan.

Komitmen dari pelaku usaha memiliki peranan penting dalam menjaga kelangsungan hidup usaha. Berwirausaha merupakan salah satu upaya dalam memperoleh pendapatan keluarga. Progam pengabdian masyarakat ini bertujuan untuk mengedukasi para pelaku usaha di desa Warnasari. Masalah utama yang sering dihadapi oleh para pelaku usaha diantaranya adalah belum adanya kesadaran untuk melakukan pencatatan keuangan usaha karena minimnya pengetahuan tentang pembukuan keuangan, berakibat pada sistem keuangan usaha yang tidak dapat membedakan antara keuntungan usaha dan kas pribadi serta menurunnya motivasi jika dihadapkan dengan permasalahan usaha sehingga berdampak pada rendahnya dalam melakukan inovasiinovasi baru.

\section{METODE PELAKSANAAN}

Sasaran pengabdian masyarakat ini adalah kepada para pemilik usaha kecil dan menengah yang berada di Desa Warnasari

Metodologi pelaksanaan dalam pengabdian pada masyarakat ini dibagi menjadi 3 (tiga) tahap yaitu tahap awal, tahap pelaksanaan dan tahap akhir. Pada tahap awal dilaksanakan observasi, dan wawancara secara langsung dengan mitra,hal ini bertujuan untuk mengetahui gambaran kondisi mitra dan untuk mengetahui permasalahan/kendala yang dihadapi oleh pelaku usaha. Tahap kedua adalah tahap pelaksanaan berupa: Pelatihan pembukuan keuangan sederhana yang dapat diaplikasikan oleh pelaku usaha, hal ini bertujuan untuk meningkatkan keterampilan dan pengetahuan mengenai manajemen keuangan usaha agar tidak tercampur antara keuangan keluarga dengan keuangan usaha, melalui pencatatan keuangan pelaku usaha dapat mengetahui perkembangan usahanya.

Tahap yang terakhir adalah tahap monitoring. Pada tahap ini, dilakukan metode coaching, dimana pemilik UMKM menunjukkan hasil pencatatan keuangannya dengan menceritakan hambatan dan kesulitan yang dihadapi dalam melakukan proses pencatatan. 


\section{HASIL DAN PEMBAHASAN}

Kegiatan pelatihan ini dilaksanakan tanggal 9 Maret 2019 di Pesantren Al Azhar Desa Warnasari Kecamatan Pangalengan dengan melakukan pelatihan pembukuan berupa pembuatan laporan keuangan yang sederhana yang diberikan oleh Dr. Teddy Hikmat Fauzi,M.Si dan Nurhayati,S.Sos,M.Si kepada pelaku usaha yang berjumlah 19 orang (data terlampir). Dimana diberikan pelatihan pembukuan sederhana terlebih dahulu dengan pengenalan istilah istilah yang ada dalam akuntansi. Selanjutnya adalah membuat laporan keuangan sederhana dengan membuat laporan arus kas dengan mencatat uang yang masuk dari hasil penjualan dan uang yang keluar untuk membeli bahan baku berdasarkan bukti-bukti bon-bon atau kuitansi yang diterima serta diklasifikasikan berdasarkan jenis bahan baku yang dibeli.

Pelatihan dilakukan satu hari sampai kepada materi laporan keuangan agar pemilik usaha dapat segera mengaplikasikan pelatihan tersebut. Selain itu diberikan alternatif lain untuk pembiayaan usaha berupa pembentukan Koperasi. Pembentukan koperasi dilakukan untuk menanggulangi modal yang terbatas agar tidak melakukan peminjaman ke perbankan yang mana harus ada jaminan dan suku bunga yang tinggi.

Dan para pelaku usaha merespon pembentukan koperasi tersebut dan berharap koperasi tersebut segara di realisasikan. Yang mana dalam pembentukan koperasi adanya simpanan pokok, simpanan wajib dan simpanan sukarela. Walaupun ada bank keliling yang memberikan pinjaman modal kepada pelaku usaha yang mana si peminjam wajib membayar setiap hari pada bulan berikutnya.

Selain pelatihan pembukuan diberikan juga motivasi wirausaha berupa pengarahan atau ceramah disertai dengan contoh pengusaha yang sukses. Motivasi pelaku usaha diharapkan dapat meningkat kreativitas dan inovasi ketika dihadapkan pada situasi kondisi usaha yang fluktuatif, khususnya di era sekarang ini. Hal ini dapat terukur dari rencana jangka menengah perusahaan dalam melakukan inovasi, baik dari segi pengembangan produk, maupun dari pengembangan system manajemen serta dengan motivasi usaha dapat meningkatkan disiplin dalam menggunakan anggaran usaha.

Sesuai dengan rencana yang telah ditentukan sebelum kegiatan pelatihan dilaksanakan, kegiatan pengabdian kepada masyarakat ini diawali dengan observasi dan wawancara dengan pelaku usaha untuk mengetahui permasalahan yang terjadi pada usahanya.

Kegiatan pelatihan yaitu pelatihan pembukuan keuangan sederhana adapun pembahasannya adalah sebagai berikut:

Memberikan edukasi kepada pelaku usaha bahwa keuangan pribadi harus dipisahkan dengan usaha jangan sampai keuntungan atau laba yang diperoleh bersatu dengan operasional rumah tangga sehari hari. Selain itu juga diberikan pelatihan membuat laporan kas sederhana yang terdiri dari pemasukan dan pengeluaran serta saldo yang mana pelaku usaha tinggal menulis berapa pengeluaran dalam satu hari, satu minggu atau satu bulan dan pemasukan dari usahanya 
sehingga dapat diketahui keuntungan yang diperoleh.

Kegiatan pelatihan ini tidak hanya satu arah, tetapi terjadi dua arah dengan adanya sesi diskusi. Diskusi berlangsung setelah penyampaian materi dengan tertib dan terarah.

Selain

pembukuan

diperkenalkan juga bentuk Koperasi yang terdiri dari simpanan pokok, simpanan wajib dan simpanan sukarela. Simpanan bisa dilakukan dalam jumlah yang tidak terlalu besar sehingga tidak memberatkan anggota yang menjadi bagian dari koperasi tersebut. Beberapa peserta menanyakan bagaimana dengan peminjam yang tidak mampu membayar karena tidak mempunyai jaminan. Saran kami adalah sebaiknya di survei/investigasi dulu peminjam tersebut apakah mempunyai jaminan berupa motor atau benda apapun yang bisa dijual agar pinjamannya tidak macet. Yang kedua yang akan melakukan peminjaman ditanyakan terlebih dahulu kebutuhannya apa sehingga bisa dibelikan barang/kebutuhannya oleh pengurus koperasi.

\section{KESIMPULAN DAN SARAN}

Kegiatan pengabdian kepada masyarakat pada pelaku usaha Di Desa Warnasari mendapat respon yang positif. Pelaku usaha mendapatkan wawasan baru, mengetahui dan termotivasi dalam menjalankan usahanya baik melalui pembukuan / pencatatan keuangan sederhana yang mudah diaplikasikan serta memupuk motivasi kewirausahaan.

Pembelajaran yang dapat diambil adalah dalam pengelolaan perusahaan, membutuhkan sistem yang terintegrasi yang saling terkait satu dengan yang lainnya. Artinya, dalam menjalankan usaha dibutuhkan komitmen yang tinggi dari pemilik usaha agar perusahaan untuk menjalankan sistem tersebut. Pembukuan keuangan sederhana tidak akan berjalan secara optimal tanpa adanya komitmen dari pelaku usaha untuk menjalankan sistem keuangan tersebut.

Saran nya adalah sebaiknya pelaku usaha meningkatkan kreativitas dan inovasi dengan memperluas jaringan usaha agar semakin meningkatkan penjualan dan pendapatan.

\section{DAFTAR REFERENSI}

Adhi Prasetyo, 2001, Smart Guide Jualan Online, Protelon,Jakarta

Buchari Alma, 2015, Manajemen Pemasaran dan Pemasaran Jasa, Alfabeta, Bandung

Danang Sunyoto, Dasar-dasar Manajemen Pemasaran, 2013, Konsep,Strategi dan Kasus, Jakarta Dwi Prastowo, 2015, Analisa Laporan Keuangan,UPP STIM YKPN , Jogjakarta

Eddy Herjanto, 2008, Manajemen Operasi, PT. Grasindo, Jakarta

Heizer, Jay, and Render, Barry, 2005, Manajemen Operasi, Buku 2 Edisi Ketujuh, Salemba Empat, Jakarta 2005 Irham Fahmi, 2017, Manajemen Produksi dan Operasi, Alfabeta,Bandung 